\title{
Purification and Characterization of Chitinolytic Enzymes Produced by Aeromonas sp. J-5003
}

\author{
Yong Un Choi, Ji Hee Kang, Myung Suk Lee and Won Jae Lee* \\ Department of Microbiology, Pukyong National University, Busan 608-737, Korea
}

(Received July 2002, Accepted January 2003)

\begin{abstract}
Chitinase and chitobiase produced by Aeromonas sp. J-5003 were purified and characterized. The chitinase was purified to 19.4 folds by gel chromatography and ion-exchange chromatography with the overall yield of $2.2 \%$ and the specific activity of 93.1 unit/mg. The purified enzyme showed a single band on SDS-PAGE with MW $54 \mathrm{kDa}$. The optimum $\mathrm{pH}$ and temperature of the purified chitinase were 7.0 and $37^{\circ} \mathrm{C}$, respectively, and this enzyme stc.ble in the range of $\mathrm{pH} 6.0$ to 10.0 below $37^{\circ} \mathrm{C} . \mathrm{Mg}^{2+}, \mathrm{Ca}^{2+}$ and $\mathrm{Na}^{+}$slightly stimulated the chitinase activity. However, $\mathrm{Hg}^{2+}$ and $\mathrm{Fe}^{3+}$ inhibited chitinase activity. The chitobiase was purified by Sephacryl HR-100 gel chromatography and DEAE-Sephadex A-50 ion-exchange chromatography with 33.5 purification folds and $4.3 \%$ yield. The purified enzyme showed a sirgle band with $\mathrm{MW} 63 \mathrm{kDa}$. The optimum $\mathrm{pH}$ and temperature of the purified chitobiase were 7.0 and $37^{\circ} \mathrm{C}$, respectively. And this enzyme was stable in the range of pH 6.0 to 9.0 and at the temperature below $37^{\circ} \mathrm{C}$. The enzyme activity was increased by $\mathrm{Mn}^{2+}$, but it was inlibited by $\mathrm{Ag}^{+}$.
\end{abstract}

Key words: Chitinase, Chitobiase, Aeromonas sp. J-5003, Purification

\section{Introduction}

Chitin is very abundant materials on earth, which is polymerized by $\beta-1,4$ linkage of $\mathrm{N}$-acetyl- $\beta$-Dglucosamine (NAG). It is often contained within crab shell, insect shell and mollusk epidermis, and produced about 100 billion ton per year. Chitin and its hydrolyzed materials are very effective in decrease of blood pressure, triglyceride and cholesterol in blood, and prevention of weight loss by cancer. It has been also reported that they improved the recovery of disease of adult people and activated the energy metabolism of cell (Kim, 1997).

There are a number of reports that chitinolytic enzyme was detected from invertebrates, fishes, amphibia, reptiles and birds (Jeuniaux, 1996; Lundblad et al., 1975; Ohtakara et al., 1978). In case of plants, chitinase is present in soybeans, wheat germ and yam (Jeur.iaux, 1961; Molano et al., 1979; $\mathrm{Si}$ and $\mathrm{Li}$, 1970; Wa Jworth and Zikakis, 1984). But, many valuable iadustrial chitinolytic enzymes are mainly

\footnotetext{
*Corresponding author: wjlee@ pknu.ac.kr
}

obtained from microorganisms. Microbial chitinases were reported in Penicillium (Fenton and Eveleigh, 1981), Saccharomyces (Molloy and Burke, 1997), Serratia (Monreal and Reese, 1969), Aeromonas (Huang et al., 1996; Mitsuhiro and Arai, 1992; Yabuki et al., 1986), Alteromonas (Hayashi et al., 1995; Tsujibo et al., 1991), Bacillus (Bhushan and Hoondai, 1998; Pelletier and Sygusch, 1990; Sakai et al., 1998) and Pseudomonas (Kang and Chung, 1999; Lee et al., 1998).

We previously isolated Aeromonas sp. J-5003 on the coast of Busan and found that this strain produced two chitinolytic enzymes, chitnase and chitobiase (Choi et al., 2003). In this study, we investigated purification and characterization of chitinase and chitobiase produced by Aeromonas sp. J-5003.

\section{Materials and Methods}

\section{Bacterial strains and media}

Aeromonas sp. J-5003, which produces chitinase and chitobiase, had been previsouly isolated and 
characterized (Choi et al., 2003). Preparation of colloidal chitin was performed by Choi et al. (2003). The medium for the production of chitinase was consisted of colloidal chitin $0.5 \%$, yeast extract $0.25 \%$, peptone $0.25 \%$, glucose $0.2 \%, \mathrm{NaCl} 1.5 \%, \mathrm{MgSO}_{4}$. $7 \mathrm{H}_{2} \mathrm{O} 0.05 \%, \mathrm{KH}_{2} \mathrm{PO}_{4} 0.03 \%, \mathrm{~K}_{2} \mathrm{HPO}_{4} 0.07 \%, \mathrm{FeSO}_{4} \cdot$ $7 \mathrm{H}_{2} \mathrm{O} 0.1 \%, \mathrm{ZnSO}_{4} 0.01 \%$ and $\mathrm{MnCl}_{2} 0.01 \%$. For chitobiase production, glucose and peptone were replaced by $0.2 \%$ galactose and $0.5 \%$ tryptone in the above medium.

\section{Purification of chitinase and chitobiase}

The bacterial preculture was inoculated into the culture medium. Initial $\mathrm{pH}$ of the medium was adjusted to 7.0 and it was incubated for $88 \mathrm{hrs}$ at $30^{\circ} \mathrm{C}$ on a rotary shaker at $210 \mathrm{rpm}$. The culture was centrifuged for $20 \mathrm{~min}$ at $4,000 \times \mathrm{g}$ using a refrigerated centrifuge to remove the cells. Solid $\left(\mathrm{NH}_{4}\right)_{2} \mathrm{SO}_{4}$ was added at $80 \%$ saturation into the supernatants. After stirring for overnight at $4^{\circ} \mathrm{C}$, the precipitate was collected by centrifugation at 4,000 $\mathrm{Xg}, 4^{\circ} \mathrm{C}$ and resuspended into $20 \mathrm{mM}$ sodium phosphate buffer ( $\mathrm{pH} 7.0$; buffer A). The collected precipitates were dialyzed with buffer $A$, and stored at $-70^{\circ} \mathrm{C}$. The frozen precipitates were used as crude enzyme preparations for further purification.

40 milliliter of the crude enzyme solution was placed on top of Sephadex G-200 column $(2.3 \times 50$ $\mathrm{cm}$, Amersham Pharmacia, Sweden) and eluted with buffer $\mathrm{A}$. The fractions containing chitinase activity were collected and concentrated. Concentrated chitinase was subjected to $1.5 \times 15 \mathrm{~cm}$ QSepharose column. The column was developed by linear gradient elution into $3.5 \mathrm{~m} \ell$ fractions using $0-1.0 \mathrm{M} \mathrm{NaCl}$ at a flow rate of $30 \mathrm{~m} \ell / \mathrm{hr}$. The active fractions were pooled and dialyzed against buffer $\mathrm{A}$ for overnight.

Purification of chitobiase was proceeded as follows: The crude enzyme was put on a Sephacryl HR-100 column $(2.3 \times 50 \mathrm{~cm})$ equilibrated with 20 $\mathrm{mM}$ sodium phosphate buffer $(\mathrm{pH} 7.0)$. Active fractions were collected, then applied to DEAESephadex A-50 column $(2.1 \times 30 \mathrm{~cm})$. The elution was performed with $0-1.0 \mathrm{M} \mathrm{NaCl}$ linear gradient. The active fractions were collected, and it's purity was determined by SDS-polyacrylamide gel electrophoresis (PAGE).

\section{SDS-PAGE}

Molecular weight and purity of the purified enzymes were assayed by SDS-PAGE, which was performed according to the method of Laemmli (1970) using $8.0 \%$ polyacrylamide gel. The gels were stained with Coomassie brilliant blue R-250.

\section{Enzyme assay}

One milliliter of chitinase solution was mixed with $1.0 \mathrm{~m} \ell$ of substrate solution $(1.0 \%$ colloidal chitin solubilized in $20 \mathrm{mM}$ sodium phosphate buffer, $\mathrm{pH}$ 7.0) and allowed to react at $37^{\circ} \mathrm{C}$ for 45 min. The reaction was terminated by boiling the reaction mixture at $100^{\circ} \mathrm{C}$ for $5-10 \mathrm{~min}$, and it was centrifuged. The supernatant was used to determine chitinase activity by dinitrosalicylic acid (DNS) assay (Miller, 1959). One unit of chitinase was defined as the amount of enzyme required to produce the reducing equivalent of $1 \mu \mathrm{mol}$ of $\mathrm{N}$-acetylglucosamine per min under the assay conditions.

Chitobiase activity was determined with the modified method of Borooah et al. (1961). The reaction mixtures contained $0.1 \mathrm{~m} \ell$ of the purified enzyme solution, $0.2 \mathrm{~m} \ell$ of $5 \mathrm{mM} \rho$-nitrophenyl-Nacetyl- $\beta$-D-glucosaminide as substrate and $0.7 \mathrm{~m} \ell$ of $0.05 \mathrm{M}$ sodium phosphate buffer. The assays were performed for $20 \mathrm{~min}$ at $37^{\circ} \mathrm{C} .2 .0 \mathrm{~m} \ell$ of $0.25 \mathrm{M} \mathrm{Na}_{2}$ $\mathrm{CO}_{3}$ was added to stop the reaction, and then $\mathrm{A}_{405}$ was measured. One unit of enzyme activity catalyzes the formation of $1 \mu$ mole of $\rho$-nitrophenol per min.

\section{Protein concentration measurement}

Protein concentration was measured by the method of Lowry (1951) with bovine serum albumin as standard material.

Effect of $\mathrm{pH}$ and temperature on the chitinase and chitobiase activity

To measure the optimum $\mathrm{pH}$ range for chitinase and chitobiase activity, the enzyme solutions ( 0.5 $\mathrm{m} \ell$ ) dissloved in different $\mathrm{pH}$ buffer were added into $0.7 \mathrm{~m} \ell$ of $1.0 \%$ of colloidal chitin substrate solution. This mixture was reacted at $37^{\circ} \mathrm{C}$ for 45 min and each of activity was assayed. Enzyme activity was also measured at various temperatures with $\mathrm{pH}$ 7.0. 
Effect of $\mathrm{pH}$ and temperature on the chitinase and chitobiase stability

Two enzymes were preincubated for $1 \mathrm{hr}$ at various $\mathrm{pH}$ values and temperatures without the substrates, and immediately the remaining activity was assayed.

Effect of metal ions on the chitinase and chitobiase activity

The effect of metal ions on enzyme activity was assayed with $\mathrm{MgCl}_{2}, \mathrm{NaCl}, \mathrm{CuCl}_{2}, \mathrm{HgCl}_{2}, \mathrm{CaCl}_{2}$, $\mathrm{ZnCl}_{2}, \mathrm{FeCl}_{3}, \mathrm{AgNO}_{3}, \mathrm{CdCl}_{2}, \mathrm{MnCl}_{2}, \mathrm{PbCl}_{2}$ and $\mathrm{KCl}$. Distilled water containing each of the metal ions was added into $0.7 \mathrm{~m} \ell$ of the enzyme solution with final concentration $1 \mathrm{mM}$ and standed for $1 \mathrm{hr}$ at $37^{\circ} \mathrm{C}$. The esidual enzyme activity was then measured.

\section{Results and Discussion}

\section{Purification of chitinase and chitobiase}

Chitinase from Aeromonas sp. J-5003 was purified to homogenity by two successive chromatographies cf Sephadex G-200 and Q-Sepharose. Purificatior procedure of chitinase from the culture supernatan was summarized in Table 1 . Chitinase was purified 19.4-fold with a yield of $2.2 \%$.

Table 1. Summary of the purification of chitinase from Aeromonas sp. J-5003

\begin{tabular}{lccccc}
\hline $\begin{array}{c}\text { Purfication } \\
\text { step }\end{array}$ & $\begin{array}{c}\text { Total } \\
\text { protein } \\
(\mathrm{mg})\end{array}$ & $\begin{array}{c}\text { Total } \\
\text { activity } \\
\text { (U) }\end{array}$ & $\begin{array}{c}\text { Specific } \\
\text { activity } \\
(\mathrm{U} / \mathrm{mg})\end{array}$ & $\begin{array}{c}\text { Yield } \\
(\%)\end{array}$ & Fold \\
\hline $\begin{array}{l}\text { Crude } \\
\text { supernatan. }\end{array}$ & $6,000.0$ & 26,449 & 4.4 & 100.0 & 1.0 \\
$\begin{array}{c}\text { Ammonium } \\
\text { sulfate }\end{array}$ & 296.4 & $7,091.4$ & 23.9 & 26.8 & 5.0 \\
$\quad \begin{array}{l}\text { precipitation } \\
\text { Sephadex G-200 }\end{array}$ & 14.1 & $1,234.2$ & 87.5 & 4.7 & 18.3 \\
Q-Sepharose & 6.2 & 576.6 & 93.1 & 2.2 & 19.4 \\
\hline
\end{tabular}

Chitobiase from the supernatant was successfully purified by ammonium sulfate precipitation and chromatography. Chitobiase was finally purified to near homogeneity by gel filtration and ion chromatography using Sephacryl HR-100 and DEAE Sephadex $A_{\mathrm{L}}-50$ about 33.5 -fold with a yield of $4.3 \%$ from culture medium. The purification procedure of chitobiase from the culture supernatant was summarized in Table 2. The final preparation gave a
Table 2. Summary of the purification of chitobiase from Aeromonas sp. J-5003

\begin{tabular}{lccccc}
\hline $\begin{array}{c}\text { Purfication } \\
\text { step }\end{array}$ & $\begin{array}{c}\text { Total } \\
\text { protein } \\
\text { (mg) }\end{array}$ & $\begin{array}{c}\text { Total } \\
\text { activity } \\
\text { (U) }\end{array}$ & $\begin{array}{c}\text { Specific } \\
\text { activity } \\
\text { (U/mg) }\end{array}$ & $\begin{array}{c}\text { Yield } \\
(\%)\end{array}$ & Fold \\
\hline $\begin{array}{c}\text { Crude } \\
\text { supernatant }\end{array}$ & $5,556.6$ & 23,219 & 4.2 & 100.0 & 1.0 \\
$\begin{array}{c}\text { Ammonium } \\
\text { sulfate } \\
\text { precipitation }\end{array}$ & 296.4 & 7,043 & 23.8 & 30.3 & 5.7 \\
$\begin{array}{c}\text { Sephacryl } \\
\text { HR-100 } \\
\text { DEAE-Sephadex } \\
\text { 1A-50 }\end{array}$ & 12.8 & 1,368 & 106.9 & 5.9 & 23.1 \\
\hline
\end{tabular}

single band in SDS-PAGE and the molecular weight of chitinase and chitobiase were estimated to be $54 \mathrm{kDa}$ and $63 \mathrm{kDa}$, respectively (Fig. 1). The purified chitobiase revealed the high value of specific activity and purity, but the recovery rate was low compared to other microbial chitobiases such as those produced by Penicillium islandicum (Fenton and Eveleigh, 1981) and Streptomyces griseus HUT 6037 (Mitsutomi et al., 1995).
(A)

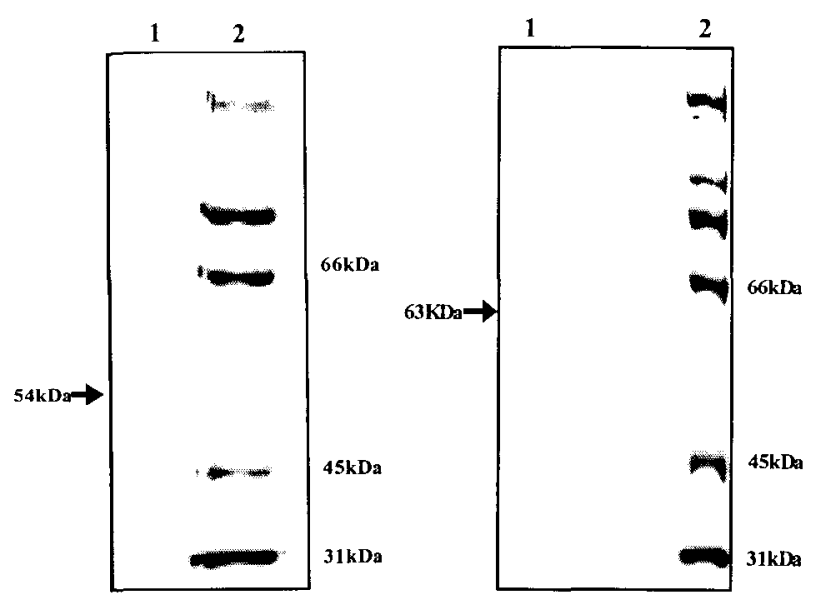

Fig. 1. SDS-PAGE of chitinase purified from Aeromonas sp. J-5003.

(A) Lane 1, Chitinase; Lane 2, Molecular size marker.

(B) Lane 1, Chitobiase; Lane 2, Molecular size marker.

Effect of $\mathrm{pH}$ and temperature on the chitinase and chitobiase activity

Effects of $\mathrm{pH}$ and temperature on chitinase activity were shown in Fig. 2. The highest activity 

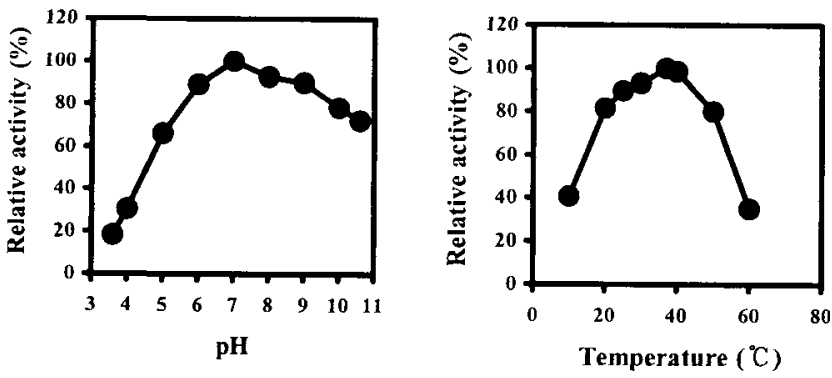

Fig. 2. Effect of $\mathrm{pH}$ and temperature on the chitinase activity.

of chitinase was observed at $\mathrm{pH}$ 7.0. And even in the wide range of $\mathrm{pH} 6.0$ to 11.0 , the enzyme showed activity more than $70 \%$. But, the chitinase activity rapidly decreased below $\mathrm{pH} 5.0$. The highest activity was obtained at $37^{\circ} \mathrm{C}$.

Optimum $\mathrm{pH}$ and temperature of the chitobiase were 7.0 and $37^{\circ} \mathrm{C}$, respectively (Fig. 3). Also the enzyme showed relatively high activity at $\mathrm{pH} 6.0-$ 9.0 and $25-50^{\circ} \mathrm{C}$.

Effect of $\mathrm{pH}$ and temperature on the chitinase and chitobiase stability

Chitinase produced by Aeromonas sp. J-5003 was stable in $\mathrm{pH} 6.0-10.0$ and below $37^{\circ} \mathrm{C}$ (Fig. 4). The enzyme was inactivated at the acidic $\mathrm{pH}$ range and above $37^{\circ} \mathrm{C}$.
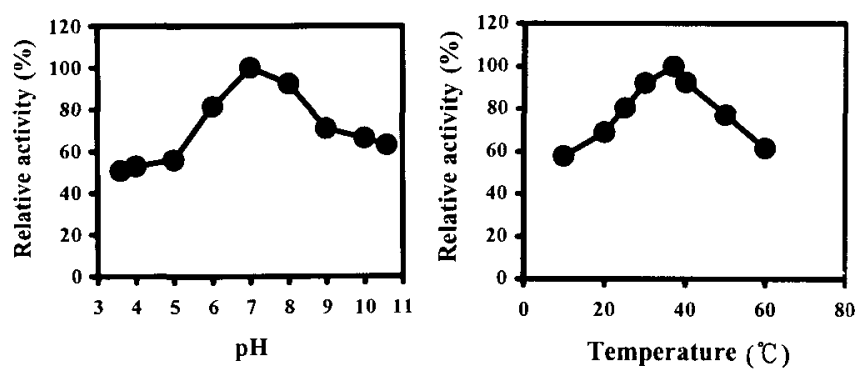

Fig. 3. Effect of $\mathrm{pH}$ and temperature on the chitobiase activity.
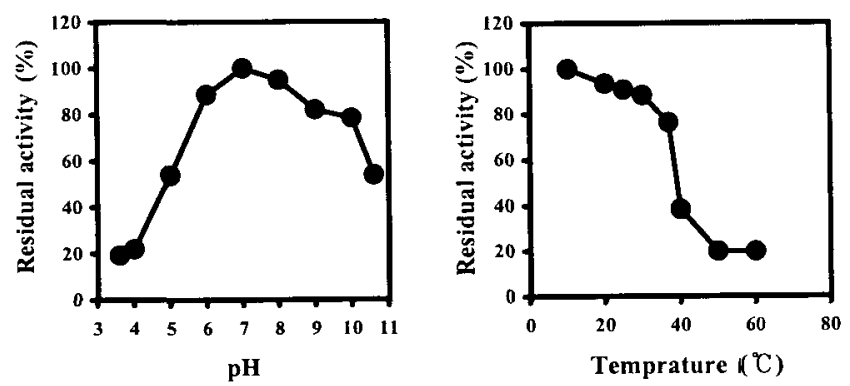

Fig. 4. Effect of $\mathrm{pH}$ and temperature on the chitinase stability.
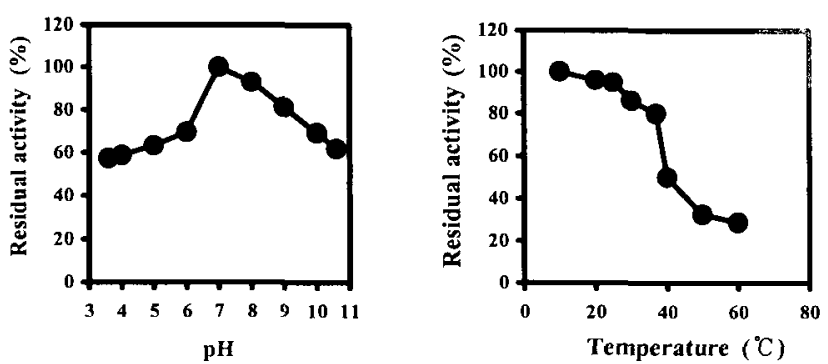

Fig. 5. Effect of $\mathrm{pH}$ and temperature on the chitobiase stability.

Chitobiase was stable at the pH 7.0-9.0 (Fig. 5). Heat stability of chitobiase was examined by maintaining the enzyme solution with various temperatures at $\mathrm{pH} 7.0$ for $1 \mathrm{hr}$. The enzyme activity more than $80 \%$ remained after treatment at $37^{\circ} \mathrm{C}$, but it was rapidly decreased above $37^{\circ} \mathrm{C}$. Yabuki et al. (1986) reported that chitobiase produced by $A$. hydrophila subsp. anaerogenes A52 retained $83 \%$ of its activity at $45^{\circ} \mathrm{C}$, and was inactivated at $55^{\circ} \mathrm{C}$. From these results, it is concluded that the chitobiase from Aeromonas sp. J-5003 was less heat stable than other microbial chitobiases.

Effect of metal ions on the chitinase and chitobiase activity

Table 3 showed effect of metal ions on the chitinase and chitobiase activity. $\mathrm{MgCl}_{2}, \mathrm{CaCl}_{2}$ and $\mathrm{NaCl}$ increased enzyme activity, but $\mathrm{FeCl}_{3}$ and $\mathrm{HgCl}_{2}$ inhibited the enzyme activity. Especially, the

Table 3. Effect of metal ions on the activity of chitinase and chitobiase produced by Aeromonas sp. J-5003

\begin{tabular}{|c|c|c|}
\hline \multirow{2}{*}{$\begin{array}{l}\text { Compounds } \\
(1 \mathrm{mM})\end{array}$} & Chitinase & Chitobiase \\
\hline & $\begin{array}{c}\text { Relative } \\
\text { activity (\%) }\end{array}$ & $\begin{array}{c}\text { Relative } \\
\text { activity (\%) }\end{array}$ \\
\hline No addition & 100.0 & 100.0 \\
\hline $\mathrm{MgCl}_{2}$ & 103.1 & 93.8 \\
\hline $\mathrm{NaCl}$ & 109.9 & 94.8 \\
\hline $\mathrm{KCl}$ & 72.0 & 96.3 \\
\hline $\mathrm{AgNO}_{3}$ & 53.6 & 65.0 \\
\hline $\mathrm{CdCl}_{2}$ & 57.6 & 90.2 \\
\hline $\mathrm{FeCl}_{3}$ & 21.6 & 91.5 \\
\hline $\mathrm{MnCl}_{2}$ & 89.6 & 104.4 \\
\hline $\mathrm{CuCl}_{2}$ & 66.4 & 97.9 \\
\hline $\mathrm{HgCl}_{2}$ & 28.1 & 92.0 \\
\hline $\mathrm{CaCl}_{2}$ & 103.9 & 90.5 \\
\hline $\mathrm{ZnCl}_{2}$ & 62.4 & 93.6 \\
\hline $\mathrm{PbCl}_{2}$ & 72.8 & 95.1 \\
\hline
\end{tabular}


inhibition by $\mathrm{HgCl}_{2}$ was commonly reported in chitinase-p.oducing microorganisms (Jeuniaux, 1961; Yabuki et al., 1986).

Effect of the various metal ions on the chitobiase activity was also investigated. In case of chitobiase, $\mathrm{MnCl}_{2}$ slig.tly increased the enzyme activity, but other metal ions had no marked effect on enzyme activity, with exception of $\mathrm{AgNO}_{3}$. These results showed that chitinase and chitobiase from Aeromonas sp. J-5003 behaved differently against individual compounds.

Chitinases were produced by various microorganisms including Saccharomyces (Molloy and Burke, 199:), Serratia (Monreal and Reese, 1969), Aeromonas (Huang et al., 1996; Mitsuhiro and Arai, 1992; Yabu xi et al., 1986), Alteromonas (Hayashi et al., 1995; Tsujibo et al., 1991), Bacillus (Bhushan and Hoondai, 1998; Pelletier and Sygusch, 1990; Sakai et al., 1998), Vibrio (Bassler et al., 1991) and fungi (Fenton and Eveleigh, 1981). It has been reported that affinity adsorption procedure was effective to purify chitinase (Jeuniaux, 1996; Yabuki et al., 1986). We also tried to use the same procedure to purify chitinase from a crude supernatant of Aeromonas sp. J-5003, but it was difficult to use the procedure because of low affinity. So, we purified this chitinolytic enzymes to homologous state by ion chromatography and gel filtration.

Various nolecular weights of the chitinase were reported or. the microbial enzymes as valued from 40 to $200 \mathrm{l}: \mathrm{Da}$. The chitinase in our preparations had MW $54 \mathrm{kDa}$. Examination of the effect of metal ions showed that this enzyme was differently affected by these ions.

In this paper, the chitobiase produced by Aeromonas sp. J-5003 showed to be an alkaline and heat-labile enzyme. But since there has been few reports dealing the characteristics of microbial chitobiases, it was not practical compare our results with other microbial chitobiases. Recently, molecular clonings of chitobiase genes from several bacteria have been reported (Chitlaru and Roseman, 996; Matsuo et al., 1999; Spindler-Barth et al., 1985; Tews et al., 1996), but it was also relatively ess than those chitinases. So, it is necessary to study the cloning and analysis of the chitobiase gene from Aeromonas sp. J-5003.

\section{References}

Bassler, B.L., C. Yu, Y.C. Lee and S. Roseman. 1991. Chitin utilization by marine bacteria: Degradation and catabolism of chitin oligosaccharides by Vibrio furnissii. J. Biol. Chem., 266, 24276-24286.

Bhushan, B. and G.S. Hoondai. 1998. Isolation, purification and properties of a thermostable chitinase from an alkalophilic Bacillus sp. BG-11. Biotech. Lett., 20, 157159.

Borooah, J., D.H. Leaback and P.G. Walker. 1961. Substrates for glucosamindase. J. Biochem., 78, 106-110.

Chitlaru, E. and S. Roseman. 1996. Molecular cloning and characterization of a novel $\beta-\mathrm{N}$-acetyl-D-glucosaminidase from Vibrio furnissii. J. Biol. Chem., 271, 33433-33439.

Choi, Y.U., J.H. Kang, M.S. Lee and W.J. Lee. 2003. Isolation and characterization of chitinase and chitobiase produced by Aeromonas sp. J-5003. J. Kor. Fish. Soc., 6, 16 (in Korean).

Fenton, D.M. and D.E. Eveleigh. 1981. Purification and mode of action of a chitosanase from Penicillium islandicum. J. Gen. Microbiol., 126, 151-165.

Hayashi, K., S. Sato, R. Takano, H. Tsujibo, H. Orikoshi, C. Imada, Y. Okami, Y. Inamori and S. Hara. 1995. Identification of the positions of disulfide bonds of chitinase from a marine bacterium, Alteromonas sp. strain O-7. Biosci. Biotech. Biochem., 59, 1981- 1982.

Huang, J.H., C.J. Chen and Y.C. Su. 1996. Production of chitinolytic enzymes from a novel species of Aeromonas. J. Ind. Microbiol., 17, 89-95.

Jeuniaux, C. 1961. Chitinase, an addition to the list of hydrolases in the digestive tract of vertebrates. Nature, $192,135-136$.

Jeuniaux, C. 1996. Chitinases. In: Methods in Enzymology, Vol. 8, E.R. Neufeld and V. Ginsberg, eds. Academic Press, New York, pp. 644-650.

Kang, S.W. and M.J. Chung. 1999. Purification of chitinase from Pseudomonas vesicularis KW-15. J. Chitin Chitosan, 4, 132-136. (in Korean)

Kim, S.K. 1997. Chitin and Chitosan; Base and Pharmacodynamics. Lee-Hwa Pub. Co. Seoul, Korea (in Korean).

Laemmli, U.K. 1970. Cleavage of structural proteins during the assembly of the head of bacteriophage T4. Nature, $227,680-685$.

Lee, J.T., D.H. Kim, J.H. Do and S.D. Kim. 1998. Purification and characterization of chitinase from antagonistic bacteria Pseudomonas sp. 3098. Kor. J. Appl. Microbiol. Biotechnol., 26, 515-522. (in Korean)

Lowry, O.H., N. Rosevrough, A.L. Farr and R.J. Randall. 19 51. Protein measurement with the folin phenol reagent. J. Biol. Chem., 193, 265-275.

Lundblad, G., M. Elander, J. Lind and K. Slettongren. 1979. Bovine serum chitinase. Eur. J. Biochem., 100, 455-460.

Matsuo, Y., M, Kurita, J.K. Park, K. Tanaka, T. Nakagawa, M. Kawamukai and H. Matsuda. 1999. Purification, characterization and gene analysis of $\mathrm{N}$-acetylglucosaminidase from Enterobacter sp. G-1. Biosci, Biotechnol. 
Biochem., 63, 1261-1268.

Miller, G.L. 1959. Use of dinitrosalicylic acid reagent for determination of reducing sugar. Anal. Chem., 31, 426428.

Mitsuhiro, R. and M. Arai. 1992. Purification and some properties of chitinases from Aeromonas sp. No. 10S-24. Biosci. Biotech. Biochem, 56, 460-464.

Mitsutomi. M., T. Hata and T. Kuwahara. 1995. Purification and characterization of novel chitinases from Stereptomyces griseus HUT 6037. J. Ferment. Bioeng., 80, 153158.

Molano, J., I. Polacheck, A. Duran and E. Cabib. 1979. An endochitinase from wheat germ. Activity on nascent and preformed chitin. J. Biol. Chem., 254, 4901-4907.

Molloy, C. and B. Burke. 1997. Expression and secretion of Janthinobacterium lividum chitinase in Saccharomyces cerevisiae. Biotech. Lett., 19, 1161-1164.

Monreal, J. and E.T. Reese. 1969. The chitinase of Serratia marcescens. Can. J. Microbiol., 15, 689-696.

Ohtakara, A., Y. Úchido and M. Mitsutomi. 1978. Proceedings of the First International Conference on Chitin/ Chitosan (R.A.A. Muzarell: E.R. Pariser, eds) MIT Sea Grant Report MITSG. 78, 587-606.

Pelletier, A. and J. Sygusch. 1990. Purification and characterization of three chitosanase activities from Bacillus megaterium P1. Appl. Environ. Microbiol., 56, 844-848.

Sakai, K., A. Yokota, H. Kurokawa, M. Wakayama and M. Moriguchi. 1998. Purification and characterization of three thermostable endochitinases of a noble Bacillus strain, $\mathrm{MH}-1$, isolated from chitin-containing compost. Appl. Environ. Microbiol., 64, 3397-3402.

Si, S.C. and Y.T. Li. 1970. Studies on the glycosidases of Jack bean meal. J. Biol. Chem., 245, 5153-5160.

Spindler-Barth, M., E. Shaaya and D. Spindler. 1986. The level of chitinolytic enzymes and ecdysteroids during larval-pupal development in Epbestia cautella and their modifications by a juvenile hormone analogue. Insect Biochem., 16, 187- 190 .

Tews, I., R. Vincentelli and C.E. Vorgias. 1996. N-acetylglucosaminidase (chitobiase) from Serratia marcescens; Gene sequence, and protein production and purification in Escherichia coli. Gene, 170, 63-67.

Tsujibo, H., Y. Yoshida, C. Imada, Y. Okami, K. Miyamoto and $Y$. Inamori. 1991. Isolation and characterization of a chitin degrading marine bacterium belonging to the genus Alteromonas. Nippon Suisan Gakkaishi, 57, 2127 $-2131$.

Wadworth, S.A. and J.P. Zikakis. 1984. Chitinase from soybean seeds; Purification and some properties of the enzyme system. J. Agric. Food Chem., 32, 1284- 1288.

Yabuki, M., K. Mizushina, T. Amatatsu, A. Ando, T. Fujii, M. Shimada and M. Yamashita. 1986. Purification and characterization of chitinase and chitobiase produced by Aeromonas hydrophila subsp. anaerogenes A52. J. Gen. Appl. Microbiol., 32, 25-38. 